\title{
Pacemaker/ICD-infekció: fókuszban a prevenció
}

\author{
Benák Attila, Sághy László
}

\author{
SZTE ÁOK, II. sz. Belgyógyászati Klinika és Kardiológiai Központ, Szeged \\ Levelezési cím: \\ Dr. Benák Attila, e-mail: benakattila@gmail.com
}

\begin{abstract}
A pacemaker- és ICD-infekciók fokozatosan emelkedő incidenciája miatt egyre nagyobb figyelem fordítódik a primer prevencióra, illetve az alternatív, transzvénás elektróda nélküli rendszerekre. Az infekció megelőzése komplex, több szintű folyamat, amely során a beteghez-, eszközhöz- és procedúrához köthető faktorokat is figyelembe kell venni. Jelen összefoglaló közlemény célja a lehetséges megelőzési gyakorlatoknak a rövid részletezése, amely magába foglalja többek között a perioperatív antikoaguláns és antibiotikumterápiát, mütéttechnikai tényezőket, antibakteriális tasak használatára vonatkozó evidenciákat, illetve rövid kitekintést ad a transzvénás elektróda extrakción átesett betegek reinfekciójának megelőzésére. Az közlemény alapját a közelmúltban megjelent, beültethető kardiális elektromos eszközök infekciójának prevenciójával, diagnózisával és kezelésével foglalkozó EHRA nemzetközi konszenzus dokumentum adja.
\end{abstract}

Kulcsszavak: pacemaker, defibrillátor, infekció, prevenció, antibakteriális tasak

\section{Pacemaker/ICD infection: focusing on the prevention}

The gradually increasing number of pacemaker and ICD infection requires more focus on primary prevention and alternative systems such as the leadless pacemakers and the subcutaneous ICDs. Infection prevention is a complex, multi-level process, which desires acknowledgments of the patient-, device- and periprocedural factors. The current review is aiming to provide an overview of the possible strategies of infection prevention, such as the perioperative anticoagulant and antibiotic therapy, surgical techniques, usage of the antibacterial envelope, and the prevention of reinfection after successful transvenous lead removal. The review is based on the recently published EHRA international consensus document on how to prevent, diagnose, and treat cardiac implantable electronic device infections.

Keywords: pacemaker, defibrillator, infection, prevention, antibacterial envelope

\section{Bevezetés}

A pacemaker (PM), illetve implantábilis kardioverterdefibrillátorok (ICD) fertőzése az egyik legveszélyesebb komplikáció, amivel ezen eszközök implantációját követően számolni kell. Jelentős mortalitása mellett komoly kihívást jelentenek az egészségügyi ellátórendszernek, ugyanis hosszas komplex kezelést igénylő kórházi bennfekvéssel járhatnak. Számuk nagyjából a kétezres évek közepe óta fokozatosan emelkedik. A sokáig viszonylag stagnáló 1,5\% körüli arány jelenleg már egyes nagy esetszámú vizsgálatokban meghaladja a $3 \%$-ot (1). Ennek fő oka, hogy egyre több komorbiditással rendelkező betegek körében történik egyre komplexebb eszközök implantációja. Tekintettel az egyre nagyobb jelentőségű problémára, több multicentrikus vizsgálat folyt a primer prevenció témakörében, amelynek eredményei az utóbbi években kerültek nyilvánosságra. Ezen összefoglaló közlemény alapját a nemrégiben megjelent EHRA-konszenzus dokumentum adja, amely - többek között - kiterjedten foglalkozik a PM/ ICD-infekciók megelőzésével (2).

A kézirat 2020. 06. 04-én érkezett a szerkesztőségbe, 2020. 06. 15-én került elfogadásra. 


\section{Infekcióprevenció}

Az PM/ICD-infekciók eredményes megelőzése komplex, többtényezős folyamat. A beteghez köthető tényezőket $(3,4)$ az 1. táblázat mutatja, ezeket befolyásolni csak korlátozottan lehet. A közvetlen preprocedurális láz egyértelműen emeli a későbbi fertőzéses szövődmény előfordulását, így ilyen esetben a mütét halasztása feltétlenül indokolt. A procedúrához kapcsolható faktorok (2. táblázat) már a módosítható tényezők közé tartoznak, ezek magukba foglalják az implantációs indikáció helyes megválasztását, a perioperatív antikoaguláns kezelési stratégiát, a beteg mütéti előkészítését, preventív antibiotikus kezelést, műtéttechnikai tényezőket, megfelelő sebkezelést, illetve a korábbi fertőzés miatt reimplantált új eszközök „másodlagos” infekció prevencióját is.

\section{Indikáció helyes megválasztása}

Egyszerủen fogalmazva „az az eszköz, ami nem került beültetésre, nem is lesz fertőzött". Mi sem szemlélteti jobban ennek fontosságát, miszerint az infekció miatt eltávolított PM/ICD-rendszerek egyharmadában (egyes vizsgálatokban akár 52\%-ban) definitív indikáció hiányában nem volt szükség az eszköz reimplantációjára (5). A leginkább érintettek az elsődleges megelőzés céljából javasolt ICD-k, amelyek széles körủ alkalmazása egyre inkább megkérdőjeleződik bizonyos beteg populációkban, ahol - az inszufficiens rizikóbecslés következtében - az ICD-implantációtól várható haszon összemérhető az implantációval járó akut és hosszabb távú komplikációkkal. Ezen esetekben szimplán az ajánlásokhoz való szoros ragaszkodás nem feltétlenül a legjobb stratégia, kiemelten fontos a betegek részletes tájékoztatásán alapuló döntés, amely végső soron a betegek kezében van.

\section{Perioperatív antikoaguláns és antitrombotikus terápia}

A perioperatív antikoagulálás helyes menedzsmentjének célja a mütét alatti, illetve posztoperatív vérzéses

\begin{tabular}{l|l|}
$\begin{array}{l}\text { 1. TÁBLÁZAT. Beteghez köthető PM/ICD-infekciós rizikófak- } \\
\text { torok }\end{array}$ & $\begin{array}{c}\text { Esélyhányados } \\
\text { (odds ratio) }\end{array}$ \\
\hline Rizikófaktorok & 13,9 \\
\hline $\begin{array}{l}\text { Kortikoszteroid-használat/egyéb } \\
\text { immunszupprimált állapotok }\end{array}$ & 13,4 \\
\hline Dializált beteg & 5,83 \\
\hline Láz (<24 órával az implantáció előtt) & 5,46 \\
\hline Veseelégtelenség (GFR <60 ml/min) & 4,04 \\
\hline Malignus tumor & 3,5 \\
\hline Diabetes mellitus & 3,37 \\
\hline Krónikus obstruktív tüdőbetegség & 2,57 \\
\hline Szívelégtelenség (NYHA III-IV. stádium) & N.A. \\
\hline Korábbi PM/ICD-fertőzés &
\end{tabular}

2. TÁBLÁZAT. Periprocedurális infekciórizikót csökkentő eljárások

Meggyőződni az indikáció helytállóságáról

Aktív infekció, láz esetén a beavatkozás halasztása

Minimalizálni a perifériás/centrális vénás kanülök számát Haematomaképződés esélyének csökkentése (ld. 1. ábra)

Tapasztalt operátor és asszisztencia

Antibiotikumprofilaxis

Mütéti terület előkészítése klórhexidin-alkohollal Antibakteriális tasak magas rizikójú betegekben Korai reintervenció kerülése

szövődmények minimalizálása. A klinikailag szignifikáns haematoma kialakulása majd hétszeres infekció rizikót jelent (6), így ennek megelőzése kiemelten fontos a későbbi fertőzések megelőzésében. Azon betegeknél, ahol a becsült éves stroke-rizikó $5 \%$ alatti $\left(\mathrm{CHA}_{2} \mathrm{DS}_{2}\right.$-VASc Score <4, vénás tromboembólia $>12$ hónapja, aorta-mübillentyü, egyéb stroke-rizikó hiányában) a perioperatív időszakra az antikoaguláns terápia felfüggesztése javasolt. Ahol a magas stroke-rizikó ezt nem teszi lehetővé, ott az orális antikoaguláns terápia folytatása indokolt. Ezen ajánlásnak az alapját a BRUISE CONTROL-vizsgálat adja, amelyben a heparináthidaló kezelést hasonlították össze a terápiás INR mellett végzett operációkkal (7). Míg az utóbbi csoportban klinikailag szignifikáns haematoma 3,5\%-ban fordult elő, addig a heparináthidalásnál 16\%-ban. Ennek egyik magyarázata lehet a szerzők által „,antikoaguláns stressz-tesztnek" nevezett koncepció, amely szerint a folyamatos antikoagulálás mellett végzett mütét alatt minden jelentős vérzés ellátható, míg heparináthidalásnál ezek „rejtve” maradhatnak és a későbbi terápiás heparindózis mellett jelentős méretü haematomát okozhatnak. A BRUISE CONTROL-2 a folyamatos, illetve a perioperatív időszakra megszakított direkt orális antikoaguláns (DOAC) kezelést vizsgálta (8). Mindkét csoportban hasonlóan alacsony $(2,1 \%$ vs. $2,1 \%)$ volt a posztoperatív haematoma kialakulása, így a klinikai körülmények függvényében mindkét stratégia elfogadható választás.

Az antitrombotikus terápia vonatkozásában leginkább veszélyeztetettek a kettős aggregációgátlás (DAPT) alatt álló betegek, akiknél a haematoma kialakulásának esélye $10 \%$ feletti (9). Kiemelten fontos tehát - föleg elektív beavatkozások esetén - hogy a feleslegesen, nem ajánlásszerủen DAPT-kezelésben részesülöknél a mütét előtt legalább öt nappal az egyik aggregációgátló elhagyásra kerüljön.

A vérzéses rizikót az elöbb említetteken felül egyéb beteghez-, illetve procedurához köthető tényezők is növelik (9). Ezek közül kiemelendő a szisztolés szívelégtelenség, illetve a defibrillátor beültetése, amely esetekben fokozott a haematomaképződés esélye, függetlenül a meglévő antikoaguláns kezeléstől. Összes- 


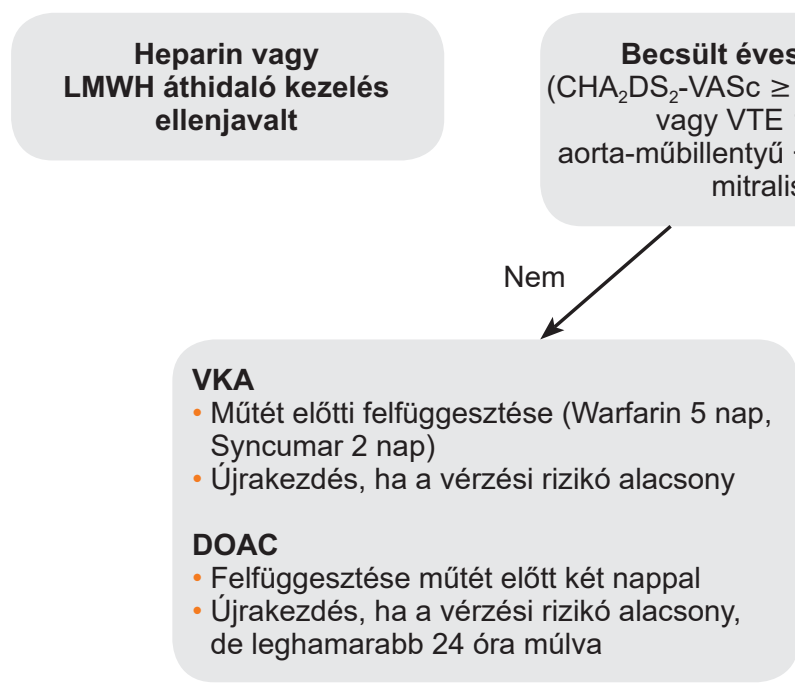

1. ÁBRA. Antikoaguláns kezelési stratégia a pacemaker/defibrillátor-implantációk perioperatív időszakára. DOAC: direkt orális antikoaguláns; LMWH: alacsony molekulatömegű heparin; TAG: trombocitaaggregáció-gátló; VKA: K-vitamin-antagonista; VTE: vénás tromboembólia

ségében tehát elmondható, hogy a perioperatív antikoaguláns kezelés egy komplex, individualizált döntés, amely kapcsán a tromboembóliás és a vérzéses rizikó összevetésével kell meghatározni a beteg számára legideálisabb stratégiát.

A kialakult haematoma punkciója az infekció kialakulását tovább fokozhatja, így ennek elvégzése szigorúan ellenjavallt. A zsebrevízió és haematoma-evakuáció csak igen indokolt esetben (feszülő, fájdalmas, illetve fenyegető dehiszcencia) javasolt (2). Mindezek alapján a javasolt perioperatív kezelési stratégiát az 1. ábra foglalja össze.

\section{Preventív antibiotikus kezelés}

Mára már széles körben elfogadott módszer a mütét előtti antibiotikus (AB) profilaxis, amelynek alapját a 2008-ban publikált randomizált, kontrollált vizsgálat adja (10). Ebben a kettős vak vizsgálatban a preoperatív cefazolinkezelés szignifikánsan csökkentette mind a zsebre lokalizálódó, mind pedig a szisztémás infekciókat. Az antibiotikumkezelés lényege, hogy a metszés pillanatában megfelelő szöveti koncentrációban legyen jelen, így helyes gyakorlat szerint az AB beadásának ideje iv. cefazolin esetén 60 perccel, míg iv. vancomycin esetében pedig 120 perccel a bőrmetszés előtt történik. A preoperatív kezeléssel ellentétben az intra-, illetve posztoperatív AB-profilaxis erősen megkérdőjelezhető. A PADIT-vizsgálat a konvencionális kezelést hasonlította össze az inkrementális AB-kezeléssel, amely magában foglalta a preoperatív cefazolin és vancomycin adását, intraoperatív bacitracinos zseböblítést, illetve posztoperatív orális cefalosporin adását. A két csoport között infekció tekintetében nem sikerült statisztikailag szignifikáns különbséget kimutatni (kontrollcsoport $1,03 \%$ vs. inkrementális csoport $0,78 \%$ ), így egyelőre erős evidencia nem támasztja alá ezen preventív eljárások hatékonyságát. Ezzel ellentétben a felszívódó, antibakteriális tasak (TYRX, Medtronic) hatékonyságát - számos retrospektív vizsgálatot követöen - egy közelmúltban publikált randomizált kontrollált vizsgálattal (WRAP-IT) is sikerült alátámasztani (11). Ezen felszívódó polimerből készült tasak a PM/ICD-infekciókért felelős baktériumok széles spektrumát lefedő monocyclint és rifampicint tartalmaz, amelyeknek egyenletes koncentrációját biztosítja a generátorzsebben egy héten keresztül. Infekció szempontjából magasabb rizikójú beavatkozásnak számít a generátorcsere, zsebrevízió, ICD vagy biventricularis eszközre történő upgrade, illetve de novo reszinkronizációs defibrillátor-implantáció. Ezen beavatkozások után az antibakteriális tasak használata közel felére csökkentette a PM/ICD-fertőzés előfordulását $(0,7 \%$ vs. 1,2\%). Ami mindkét előbb említett vizsgálatból szembetűnő, hogy a kontrollcsoportban jóval alacsonyabb volt az infekció előfordulása, mint a bevezetőben említett nagy regiszterek alapján várni lehetett volna. Ez feltehetően azzal a jelenséggel magyarázható, hogy a vizsgálatba bevont betegnél sokkal szigorúbban betartották az egyébként is használatos infekciókontroll-stratégiákat. Ez arra a fontos tényre hívja fel a figyelmet, hogy pusztán a konvencionális eljárások szigorú betartásával majd felére lehetne csökkenteni a fertőzések incidenciáját.

\section{Mứtéttechnikai tényezők}

Az aszepszis és antiszepszis technikák szigorú betartása minden invazív beavatkozásnál, így PM- és ICD-implantációk esetében is elengedhetetlen. Sebészi, illetve centrális vénás és artériás kanülök esetében a bőr klórhexidin-alkohollal történő antiszeptikus előkészítése után kevesebb fertőzést észleltek, mint a 


\begin{tabular}{|c|c|}
\hline $\begin{array}{l}\text { Izolált zsebfertőzés } \\
\text { (negatív hemokultúra) }\end{array}$ & $\begin{array}{l}\text { Szisztémás infekció } \\
\text { elektróda- vagy } \\
\text { billentyüvegetáció nélkül }\end{array}$ \\
\hline$\downarrow$ & $\nabla$ \\
\hline $\begin{array}{l}\text { Posztop. AB-kezelés 10-14 } \\
\text { napig } \\
\text { Pozitív tenyésztés esetén } \\
\text { célzottan (MSS esetén } \\
\text { flucloxacillin) } \\
\text { - Orális AB-ra váltás a } \\
\text { klinikum függvényében el- } \\
\text { fogadható (első generációs } \\
\text { cefalosporin) }\end{array}$ & $\begin{array}{l}\text { Posztop. AB-kezelés } \\
4 \text { hétig } \\
\text { - Negatív posztop. TEE és } \\
\text { hemokultúra esetén } 2 \text { hét } \\
\text { elegendő lehet, ha megfele- } \\
\text { lő klinikai javulás látható } \\
\text { - MSS esetén flucloxacillin } \\
\text { (alternatíva első generációs } \\
\text { CSP) }\end{array}$ \\
\hline
\end{tabular}

Szisztémás infekció elektródaés/vagy billentyüvegetációval (=PM/ICD-endocarditis)

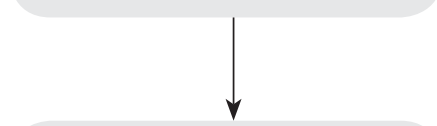

Posztop. AB-kezelés natív billentyü esetén 4 hét, mübillentyü esetén 6 hét AB-kezelés a 2015 ESC endocarditis ajánlás alapján

2. ÁBRA. Fertőzött pacemaker/defibrillátorrendszer eltávolítását követő antibiotikumkezelési ajánlás. AB: antibiotikum; CSP: cefalosporin; ICD: implantábilis kardioverter defibrillátor; MSS: meticillinszenzitív Staphylococcus; PM: pacemaker; TEE: transoesophagealis echokardiográfia

povidin-jodid esetében (12). Ugyan hasonló tanulmány PM/ICD-implantációk esetében mindezidáig nem történt, de előbbi eredmények alapján az EHRA-konszenzus-dokumentum a klórhexidinnel történő előkészítést javasolja. A generátor körül kialakult kapszula eltávolítása a későbbi vérzéses komplikációkat növelheti, így ennek rutinszerü alkalmazása nem javasolt. A már korábban említett antibiotikus és antiszeptikus zsebirrigáció hasznát a PADIT-vizsgálat nem igazolta, így ezek klinikai gyakorlata szintén nem ajánlott.

\section{Fertőzött rendszer eltávolítása utáni „„másodllagos" prevenció}

A fertőzött PM/ICD-rendszer komplett eltávolítását követően a reimplantáció szükségességének alapos elbírálása elengedhetetlen. Mint már korábban említésre került, az esetek közel felében elkerülhető volt a reoperáció. Ennek lehetséges okai: az indikáció jelen ismereteink szerint már megkérdőjelezhető, érvényét vesztette vagy akár már a kezdetektől foga sem volt helytálló. Ismert tény, hogy a sikeres transzvénás vagy sebészi extrakción és reimplantáción átesett betegek körében magasabb a reinfekciós arány, amely magyarázható a már korábban is meglévő prediszponáló társbetegségekkel, extrakciót követően észlelhető remnantokkal („ghost”ok), illetve a reimplantáció és/vagy a posztoperatív antibiotikumkezelés idejének helytelen megválasztásával (13-15). Utóbbira az EHRA-konszenzus egyértelmű útmutatás ad, ennek részleteit a 2. ábra mutatja. A reimplantáció idejére vonatkozó erős evidencia nem áll rendelkezésre, így a meglévő konszenzus alapján akkor ajánlott elvégezni, ha már lokális és szisztémás infekciós jelek nincsenek, illetve a hemokultúrák legalább 72 órája negatívak. Billentyűn lévő vegetáció esetén leg- alább 14 napot javasolt várni, a pontos reimplantáció időpontja komplex döntési folyamat, amely során figyelembe kell venni a klinikai, mikrobiológiai és képalkotó vizsgálatok eredményeit. Megfontolandó továbbá, hogy a konvencionális PM/ICD-rendszerek helyett, az utóbbi években egyre nagyobb számban alkalmazott szubkután ICD, illetve elektróda nélküli ún. „leadless pacemaker" (LPM) kerüljön implantációra. Előbbi egyértelmű előnye, hogy nem kerül idegen test a véráramba, így a potenciálisan magas mortalitású szisztémás infekciók előfordulása minimális, a lokális infekciók pedig könynyebben menedzselhetők. Az utóbbi esetében az eddig rendelkezésre álló adatok alapján szisztémás infekció előfordulása lényegesen alacsonyabb a konvencionális rendszerekéhez képest (16). Ennek oka részben, hogy az LPM felülete töredéke a PM/ICD-elektródákhoz hasonlítva $\left(\sim 546 \mathrm{~mm}^{2}\right.$ vs. $\left.\sim 3500 \mathrm{~mm}^{2}\right)$, illetve a részleges vagy teljes endothelizáció meggátolja a bakteriális biofilmképződést (16-18).

\section{Ko̊vetkeztetések}

Összefoglalásként elmondható, hogy a PM/ICD-fertőzések megelőzéséhez számos tényező figyelembevétele szükséges, amelyek pontos és szigorú betartása vezethet a jelenleg növekvő incidencia megállításához. Fontos lenne a hazai gyakorlatban rutinszerüen bevezetni az antibakteriális tasak használatát magas infekciórizikó esetén, valamint válogatott esetekben a szubkután ICD és az LPM előnyben részesítését „prevenciós" indikációval.

\section{Nyilatkozat}

A szerzők kijelentik, hogy az összefoglaló közlemény megírásával kapcsolatban nem áll fenn velük szemben 
pénzügyi vagy egyéb lényeges összeütközés, összeférhetetlenségi ok, amely befolyásolhatja a közleményben bemutatott eredményeket, az abból levont következtetéseket vagy azok értelmezését.

\section{Irodalom}

1. Joy PS, et al. Cardiac implantable electronic device infections: Who is at greatest risk? Heart Rhythm 2017; 14(6): 839-845. DOI: 10.1016/j.hrthm.2017.03.019

2. Blomström-Lundqvist $C$, et al. European Heart Rhythm Association (EHRA) international consensus document on how to prevent, diagnose, and treat cardiac implantable electronic device infectionsendorsed by the Heart Rhythm Society (HRS), the Asia Pacific Heart Rhythm Society (APHRS), the Latin American Heart Rhythm Society (LAHRS), International Society for Cardiovascular Infectious Diseases (ISCVID), and the European Society of Clinical Microbiology and Infectious Diseases (ESCMID) in collaboration with the European Association for Cardio-Thoracic Surgery (EACTS). Eur Heart J 2020. DOI: 10.1093/europace/euz246

3. Klug $D$, et al. Risk factors related to infections of implanted pacemakers and cardioverter-defibrillators: results of a large prospective study. Circulation 2007; 116(12): 1349-55. DOI: 10.1161/CIRCULATIONAHA.106.678664

4. Sohail MR, et al. Risk factor analysis of permanent pacemaker infection. Clin Infect Dis 2007; 45(2): 166-73. DOI: 10.1086/518889 5. Sohail MR, et al. Management and outcome of permanent pacemaker and implantable cardioverter-defibrillator infections. J Am Coll Cardiol 2007; 49(18): 1851-9. DOI: 10.1016/j.jacc.2007.01.072 6. Essebag V, et al. Clinically Significant Pocket Hematoma Increases Long-Term Risk of Device Infection: BRUISE CONTROL INFECTION Study. J Am Coll Cardiol 2016; 67(11): 1300-8. DOI: 10.1016/j. jacc.2016.01.009

7. Birnie $\mathrm{DH}$, et al. Pacemaker or defibrillator surgery without interruption of anticoagulation. N Engl J Med 2013; 368(22): 2084-93. doi: 10.1056/NEJMoa1302946

8. Birnie $\mathrm{DH}$, et al. Continued vs. interrupted direct oral anticoagulants at the time of device surgery, in patients with moderate to high risk of arterial thrombo-embolic events (BRUISE CONTROL-2). Eur
Heart J 2018; 39(44): 3973-3979. DOI: 10.1093/eurheartj/ehy413 9. Yang $X$, et al. The safety and efficacy of antithrombotic therapy in patients undergoing cardiac rhythm device implantation: a metaanalysis. Europace 2015; 17(7): 1076-84. DOI: 10.1093/europace/ euu369

10. de Oliveira JC, et al. Efficacy of antibiotic prophylaxis before the implantation of pacemakers and cardioverter-defibrillators: results of a large, prospective, randomized, double-blinded, placebo-controlled trial. Circ Arrhythm Electrophysiol 2009; 2(1): 29-34. DOI: 10.1161/CIRCEP.108.795906

11. Tarakji KG, et al. Antibacterial Envelope to Prevent Cardiac Implantable Device Infection. N Engl J Med 2019; 380(20): 1895-1905. DOI: 10.1056/NEJMoa1901111

12. Mimoz O, et al. Skin antisepsis with chlorhexidine-alcohol versus povidone iodine-alcohol, with and without skin scrubbing, for prevention of intravascular-catheter-related infection (CLEAN): an open-label, multicentre, randomised, controlled, two-by-two factorial trial. The Lancet 2015; 386(10008): 2069-2077. DOI: 10.1016/ S0140-6736(15)00244-5

13. Saeed O, et al. Rate of cardiovascular implantable electronic device (CIED) re-extraction after recurrent infection. Pacing Clin Electrophysiol 2014; 37(8): 963-8. DOI: 10.1111/pace.12407

14. Chew $D$, et al. Timing of device reimplantation and reinfection rates following cardiac implantable electronic device infection: a systematic review and meta-analysis. BMJ Open 2019; 9(9): e029537. DOI: 10.1136/bmjopen-2019-029537

15. Diemberger I, et al. Predictors of long-term survival free from relapses after extraction of infected CIED. Europace 2018; 20(6): 1018-1027. DOI: 10.1093/europace/eux121

16. El-Chami MF, et al. Incidence and outcomes of systemic infections in patients with leadless pacemakers: Data from the Micra IDE study. Pacing Clin Electrophysiol 2019; 42(8): 1105-1110. DOI: 10.1111/pace. 13752

17. Vamos $M$, et al. MICRA Leadless Pacemaker on Autopsy. JACC Clin Electrophysiol 2016; 2(5): 636-637. DOI: 10.1016/j.jacep.2016.02.014

18. Kypta A, et al. Complete encapsulation of a leadless cardiac pacemaker. Clin Res Cardiol 2016; 105(1): 94. DOI: 10.1007/s00392015-0929-x 